\title{
Avaliação de tecnologias aVANÇADAS PARA O ReÚSO de ÁGUA EM INDÚSTRIA METAL-MECÂNICA
}

\author{
EVALUATION OF ADVANCED TECHNOLOGIES FOR WATER REUSE IN \\ MECHANICAL INDUSTRY
}

\begin{abstract}
AIRTON OENNING JUNIOR
Engenheiro Civil pela Fundação Universidade Regional de Blumenau (1997). Especialista em Administração Industrial pela UFPR (2001). Mestre em Engenharia de Recursos Hídricos e Ambiental pela UFPR (2006). Gerente de projetos da empresa Inotec do Brasil Ltda

\section{URIVALD PAWLOWSKY}

Engenheiro Químico pela UFPR (1965). Mestre em Ciência pela COPPE /UFRJ (1967).Ph.D pela State University of New York (1972). Professor Titular de Engenharia Ambiental da UFPR. Professor Sênior do Programa de Pós-Graduação de Engenharia de Recursos Hídricos e Ambiental da UFPR. Consultor da OMS/OPS, da GTZ do Governo Alemão, de Indústrias e de Órgãos Governamentais
\end{abstract}

Código ABES: 042/07 Recebido: 16/03/07 Aceito: 03/07/07

\section{RESUMO}

Com o objetivo de reduzir o consumo de água e o descarte do efluente tratado de uma indústria metal-mecânica foi proposta a avaliação técnica e econômica de cinco tecnologias de tratamento que pudessem proporcionar a reutilização do efluente. Foram levantados quatro locais para reúso e sugeridos critérios para cada um deles. Foi constatado que na adsorção com carvão ativado e na osmose reversa o efluente tratado por estes processos poderia ser reutilizado nos locais propostos e, com vazão de reúso de $2,5 \mathrm{~m}^{3} / \mathrm{h}$, os custos ficaram em US\$ $1,14 / \mathrm{m}^{3}$ e US $\$ 1,70 / \mathrm{m}^{3}$ respectivamente. Para o ozônio e o dióxido de cloro, mesmo desinfetando o efluente, obteve-se apenas resultados satisfatórios, com custo de US $\$ 0,54 / \mathrm{m}^{3} \mathrm{e}$ US\$ $0,71 / \mathrm{m}^{3}$ respectivamente. Na coagulação/floculação todos os parâmetros analisados atenderam a dois locais de reúso, com exceção dos SDT e se obteve custo de US\$1,57/ $\mathrm{m}^{3}$.

PALAVRAS-CHAVE: Reúso de água, carvão ativado, ozônio, dióxido de cloro, osmose reversa, coagulação/floculação, indústria metal-mecânica.

\begin{abstract}
With the objective to reduce the water consumption and the discharge of effluents in a metal industry, a technical and economical evaluation of five treatment technologies was proposed in order to reuse the effluents. Four sites for water reuse were chosen and for each of them criteria were suggested. It was evidenced that in the adsorption with activated carbon and reverse osmosis the effluent treated by these processes could be reused and, with the flowrate projected of $2.5 \mathrm{~m}^{3} / \mathrm{h}$, the cost attained US\$1.14/ $\mathrm{m}^{3}$ and US\$ $1.70 / \mathrm{m}^{3}$ respectively. For the ozone and chlorine dioxide, even so the effluent was disinfected, gave only satisfactory results and the cost attained US\$ $0.54 / \mathrm{m}^{3}$ and US\$ $0.71 / \mathrm{m}^{3}$ respectively. For the treatment with coagulation/flocculation, all the analyzed parameters were successful in two reuse places, with exception of the TDS. The cost for this technology attained US\$1.57/ $\mathrm{m}^{3}$.
\end{abstract}

KEYWORDS: Water reuse, activated carbon, ozone, chlorine dioxide, reverse osmosis, coagulation/flocculation, mechanical industry.

\section{INTRODUÇÃO}

A necessidade de reduzir o desperdício e minimizar o consumo de água na indústria, aliada à leis como a 9.433 de 9 de janeiro de 1997 que instituí a cobrança pela captação de água e o lançamento de efluentes, vem forçando o setor mudar costumes e processos relacionados ao consumo de água abrindo, assim, caminho ao uso de efluente e de águas de qualidade inferior em suas instalações. Um dos conceitos mais antigos sobre reúso de água veio através da WHO - Organização Mundial da Saúde (1973) onde é definido reúso direto, indireto e reciclagem. O reúso direto é o uso planejado e deliberado de esgotos tratados para certas finalidades como irrigação, uso industrial, recarga de aquiíferos e água potável. $\mathrm{O}$ reúso indireto ocorre quando a água já usada, uma ou mais vezes para o uso doméstico ou industrial, é descarregada nas águas superficiais ou subterrâneas e utilizada novamente a jusante, de forma diluída. E a reciclagem é o reúso da água internamente às instalações industriais, tendo como objetivo a economia de água e o controle da poluição. Westerhoff (1984) classifica reúso de água em duas grandes categorias: potá- vel e não potável. O reúso potável pode ser direto e indireto, onde este último subdivide-se em recargas de aqüíferos e aumento de fontes superficiais e o não potável pode ser subdividido em reúso urbano, agrícola, recreacional, no meio ambiente, industrial, recarga de aquiíferos e em aqüicultura (EPA, 2004).

Para se utilizar do reúso, se faz necessário seguir critérios e diretrizes que podem ser encontrados em publicaçōes de órgãos governamentais como a EPA americana e a WHO e de empresas de consultoria como Metcalf \& Eddy (2003) e pesquisadores como Takashi Asano (1998). 
As tecnologias avançadas atualmente disponíveis para se tentar alcançar uma melhor qualidade nos parâmetros para água de reúso podem ser físicas, químicas e eventualmente biológicas. Tratamentos como a adsorção em carvão ativado, oxidação com ozônio, dióxido de cloro e peróxido de hidrogênio, separação por membranas (microfiltração, ultrafiltração, nanofiltração e osmose reversa), eletrólise reversa, troca iônica, destilação e precipitação química são o estado da arte no que se refere ao tratamento da águas residuárias para reúso (Mierzwa, 2005; Metcalf \& Eddy, 2003; Mancuso e Santos, 2003). A escolha de uma ou a combinação entre duas ou mais técnicas, sempre dependerá do potencial de cada técnica, dos mecanismos envolvidos na redução do contaminante de interesse (Mierzwa, 2005) e da qualidade da água de reúso que se necessita.

Com o intuito de reduzir o consumo de água e também do descarte do efluente tratado por lagoas de uma indústria metal-mecânica este trabalho tem por objetivo a avaliação técnica e econômica de cinco tecnologias de tratamento avançadas que possam proporcionar a reutilização do efluente dentro da unidade fabril. Foram levantados potenciais locais para reúso e sugeridos critérios e diretrizes para cada um deles mediante informações coletadas na indústria e na literatura disponível. Foi também efetuado avaliação dos custos diretos de implantação, manutenção e operação das estações de reúso em escala industrial para uma vazão de $2,5 \mathrm{~m}^{3} / \mathrm{h}$ em regime contínuo com o objetivo de obter uma escala de valor para as configurações propostas e comparar seus custos entre si.

\section{METODOLOGIA}

\section{Materiais}

\section{A indústria de assentos automotivos}

A indústria deste estudo de caso está situada na RMC - Região Metropolitana de Curitiba - e atua em diferentes áreas, fornecendo desde componentes, serviços de pintura, estruturas metálicas e os bancos automotivos completos. Seu processo de fabricação e pintura ocorre com a entrega das estruturas metálicas dos bancos já estampadas pelos fornecedores onde estas peças recebem banhos para desengraxe em um TTS - Túnel de Tratamento de Superfície e posteriormente seguem para tanque de imersão onde recebem a pintura pelo processo cataforético. Após a pintura as peças são secas em estufa a $155^{\circ} \mathrm{C}$ por 45 minutos e depois estocadas. $\mathrm{O}$ efluente gerado na indústria provém de duas correntes: (1) o esgoto sanitário compreendido pelos banheiros e refeitório industrial com vazão de $25 \mathrm{~m}^{3} /$ dia e (2) da linha de produção através do excedente dos enxágües e banhos que caem em calhas de coleta e de descartes programados de efluente concentrado com vazão de $35 \mathrm{~m}^{3} /$ dia. O tratamento do efluente ocorre em três etapas: (1) tratamento por fossa séptica e lodos ativados do esgoto sanitário, (2) tratamento físico-químico do efluente industrial proveniente da linha de pintura e (3) a mistura das duas correntes para tratamento final em duas lagoas aeradas em série e lagoa de polimento.

$\mathrm{Na}$ obtenção do potencial de reúso de efluentes deve considerar, inicialmente, as atividades nas quais pode-se utilizar o efluente disponível, a demanda de água exigida e os requisitos de qualidade para a água. No caso da indústria estudada, as atividades com potencial para aplicação da prática de reúso de efluentes, foram as seguintes: (1) processo de pintura; (2) reposição de perdas em torres de resfriamento; (3) lavagem de pisos; (4) irrigação de áreas verdes industriais, e descarga sanitária. O consumo diário de água para cada aplicação é obtido por meio das informaçôes referentes à freqüência de uso e ao valor da grandeza pela qual o consumo de água é expresso conforme apresentado na Tabela 1 .

Os critérios adotados para os quatro potenciais locais de consumo de água recuperada foram baseados em informaçóes coletadas na indústria e na literatura (Florencio, 2006; EPA 2004; Metcalf \& Eddy, 2003), conforme Tabela 2.

\section{Água residuária}

Foi utilizado o efluente final da estação de tratamento de efluentes de indústria metal-mecânica, ou seja, efluente coletado da saída da lagoa de polimento. A Tabela 3 apresenta os valores obtidos nas análises realizadas neste efluente tratado e tratado com filtração para cada uma das coletas feitas na indústria as quais foram utiliza-

Tabela I - Demanda de água recuperada por aplicação

\begin{tabular}{|c|c|c|c|c|}
\hline Aplicação & $\begin{array}{l}\text { Demanda } \\
\text { específica }\end{array}$ & Unidades & $\begin{array}{c}\text { Freqüência } \\
\text { de uso }\end{array}$ & $\begin{array}{r}\text { Demanda } \\
\text { diária }\left(\mathrm{m}^{3}\right) \\
\end{array}$ \\
\hline $\begin{array}{c}\text { Água de processo } \\
\text { (Pintura) }\end{array}$ & $\mathrm{x}$ & $\mathrm{x}$ & $\mathrm{x}$ & $35,0^{(1)}$ \\
\hline $\begin{array}{c}\text { Torres de } \\
\text { resfriamento }\end{array}$ & $\mathrm{x}$ & $\mathrm{x}$ & $\mathrm{x}$ & $0,2^{(1)}$ \\
\hline Lavagem de pisos & $1,4 \mathrm{~L} / \mathrm{m}^{2(2)}$ & $18.213 \mathrm{~m}^{2(3)}$ & Diária ${ }^{(3)}$ & 25,5 \\
\hline $\begin{array}{l}\text { Irrigação de áreas } \\
\text { verdes industriais }\end{array}$ & $2 \mathrm{~L} / \mathrm{m}^{2} \cdot \mathrm{dia}^{(4)}$ & $1.700 \mathrm{~m}^{2}$ & Diária $^{(4)}$ & 3,4 \\
\hline \multirow[t]{2}{*}{ Descarga Sanitária } & $6 \mathrm{~L} /$ descarga ${ }^{(4)}$ & 676 funcionários ${ }^{(1)}$ & 3 vezes/dia.funcionário ${ }^{(4)}$ & 12,2 \\
\hline & & Total & & 76,3 \\
\hline
\end{tabular}


das para os ensaios de bancada. Para filtração do efluente foi utilizado papel filtro quantitativo com as seguintes características: (1) marca: Framex; (2) dimensôes: $\varnothing 12,5 \pm 0,10 \mathrm{~cm}$; (3) especificações: 3892 - Faixa branca $6,0 \mu \mathrm{m}$, cinza: $\leq 0,0009 \mathrm{~g}$.
Unidades experimentais

Foram utilizadas cinco unidades experimentais de tratamento avançado, sendo elas:

Carvão ativado

O carvão ativado granular utilizado na pesquisa foi fornecido pela empresa Indústrias Químicas Carbomafra S.A., e possuía as seguintes características: nome: Carbono Ativado 119; granulometria (Nominal, ASTM D 2862/70): 12 x 40 mesh; $n^{\circ}$ de iodo (mg I $/$ g C.A., AWWA B 600/78): 914 mg I /g; pH: 9,7; conteúdo de cinzas (ASTM D 2866/83): 7,67\%; umidade

Tabela 2 - Requisitos físico-químicos e microbiológicos mínimos necessários para reutilização de água recuperada

\begin{tabular}{|c|c|c|c|c|c|}
\hline \multirow[t]{2}{*}{ Parâmetros } & \multirow[t]{2}{*}{ Unidade } & \multicolumn{4}{|c|}{ Potenciais locais de consumo de água recuperada } \\
\hline & & $\begin{array}{c}\text { Água de } \\
\text { processo (pintura) }\end{array}$ & $\begin{array}{l}\text { Torres de } \\
\text { resfriamento }\end{array}$ & $\begin{array}{l}\text { Lavagem de pisos e irrigação } \\
\text { de áreas verdes industriais }\end{array}$ & $\begin{array}{l}\text { Descarga } \\
\text { sanitária }\end{array}$ \\
\hline Temperatura & ${ }^{\circ} \mathrm{C}$ & Ambiente & Ambiente & Ambiente & Ambiente \\
\hline $\mathrm{pH}$ & $\sim$ & $6-8^{(1)}$ & $6-9^{(2)}$ & $6-9^{(2)}$ & $6-9^{(2)}$ \\
\hline Turbidez & NTU & $\leq 2^{(8)}$ & $\leq 3^{(4)}$ & $\leq 2^{(2)}$ & $\leq 5^{(6)}$ \\
\hline Cor & Hazen & $\leq 20^{(7)}$ & SE & $\leq 15^{(6)}$ & $\leq 15^{(6)}$ \\
\hline DQO & $\mathrm{mg} / \mathrm{L}$ & $\leq 50^{(9)}$ & $\leq 75(5)$ & $\leq 25^{(11)}$ & $\leq 75^{(11)}$ \\
\hline $\mathrm{DBO} 5$ & $\mathrm{mg} / \mathrm{L}$ & $\leq 30^{(8)}$ & $\leq 30^{(2)}$ & $\leq 10^{(2)}$ & $\leq 30^{(10)}$ \\
\hline CT & $\mathrm{mg} / \mathrm{L}$ & SE & SE & SE & SE \\
\hline COT & $\mathrm{mg} / \mathrm{L}$ & SE & SE & SE & SE \\
\hline $\mathrm{CI}$ & $\mathrm{mg} / \mathrm{L}$ & SE & SE & SE & SE \\
\hline ST & $\mathrm{mg} / \mathrm{L}$ & $\leq 1005$ & $\leq 530$ & SE & SE \\
\hline SST & $\mathrm{mg} / \mathrm{L}$ & $\leq 5^{(7)}$ & $\leq 30^{(2)}$ & SE & SE \\
\hline SDT & $\mathrm{mg} / \mathrm{L}$ & $\leq 1000^{(7)}$ & $\leq 500^{(5)}$ & $\leq 1000^{(6)}$ & $\leq 1000^{(6)}$ \\
\hline Coliformes totais & $\mathrm{NMP} / 100 \mathrm{~mL}$ & $\leq 2,2^{(8)}$ & SE & SE & SE \\
\hline Coliformes fecais & $\mathrm{NMP} / 100 \mathrm{~mL}$ & Ausente ${ }^{(9)}$ & $\leq 200^{(2)}$ & Ausente ${ }^{(2)}$ & $\leq 1000^{(10)}$ \\
\hline Condutividade & $\mu . S / c m$ & SE & $800-1200^{(3)}$ & SE & SE \\
\hline Dureza & $\mathrm{mg} / \mathrm{L} \mathrm{CaCO}_{3}$ & $\leq 30^{(1)}$ & $50-180^{(3)}$ & $\leq 500^{(6)}$ & $\leq 500^{(6)}$ \\
\hline 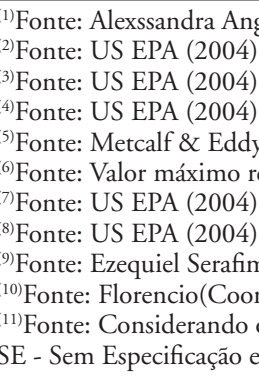 & $\begin{array}{l}\text { lino, contato pessoa } \\
\text { valores para a cidade } \\
\text { valores para o estado } \\
\text { (2003) } \\
\text { comendado para águ } \\
\text { utilizado valores par } \\
\text { valores para o estado } \\
\text { contato pessoal, }(2 \text { } \\
\text { lenadora), FINEP/P } \\
\text { valor da DQO } 2,5 \\
\text { contrada }\end{array}$ & $\begin{array}{l}\text { (2006) } \\
\text { e San Francisco } \\
\text { o Texas } \\
\text { portável, de acordo com a } \\
\text { gua de processo em indú } \\
\text { e Washington } \\
\text { 6) OSAB 4, (2006) } \\
\text { es maior que a DBO }\end{array}$ & $\begin{array}{l}\text { Portaria do Minis } \\
\text { trias químicas }\end{array}$ & da Saúde no 518 de 25/03/2004 & \\
\hline
\end{tabular}

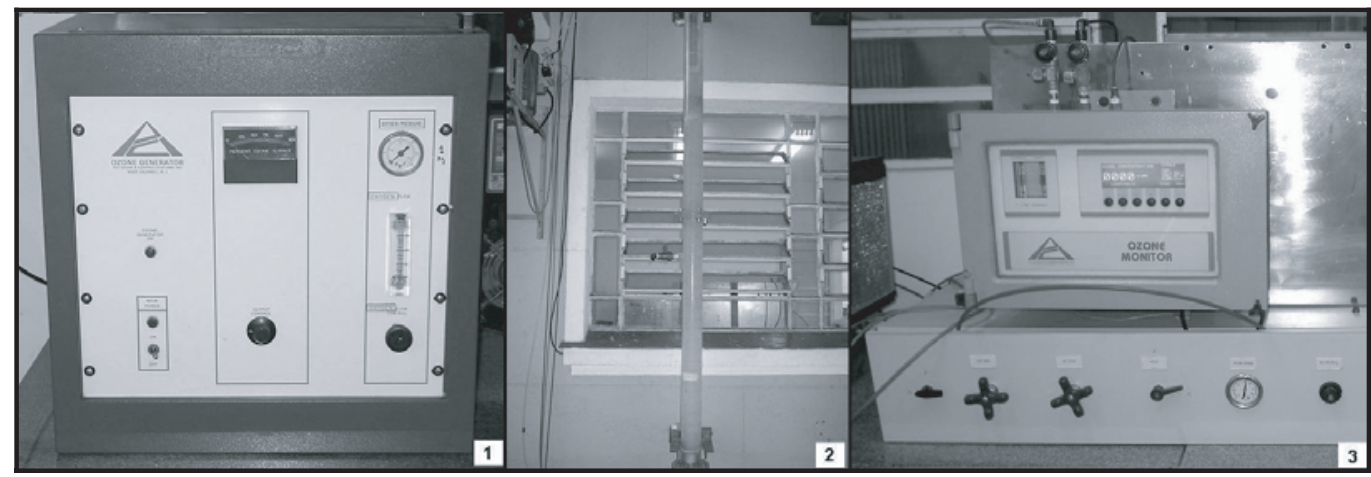

Figura I - Gerador de ozônio (I), coluna de contato para ozonização (2) e medidor de ozônio (3) Oxidação com Dióxido de cloro 


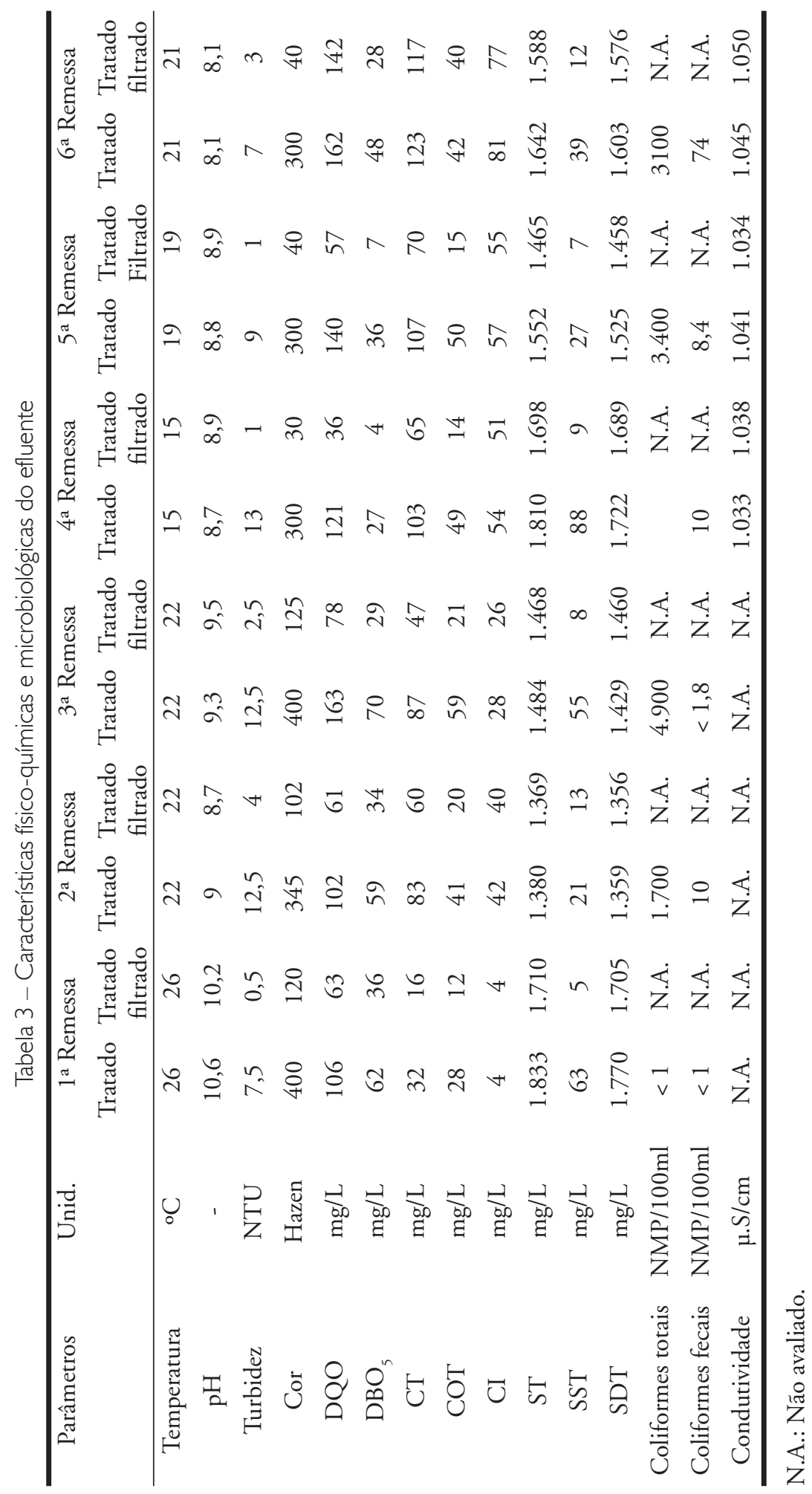


(ASTM D 2867/70): 6,25\%; peso específico aparente (ASTM D 2854/70): $0,52 \mathrm{~g} / \mathrm{m}^{3}$; dureza (ASTM D 3802/79): $97 \%$. Aárea superficial não foi informada. Para promover os ensaios de mistura do carvão ativado com o efluente foi utilizado um misturador da marca Laborquímica, com agitação por tração mecânica e velocidade de $70 \mathrm{rpm}$.

Oxidação com ozônio

A forma usada para produção de ozônio foi através do uso de oxigênio. Nos testes de ozonização foi utilizado um ozonizador em escala de bancada marca W. CALDWELL N. J., modelo CL-1, o qual possuía as seguintes características: capacidade nominal de produção de ozônio: $35 \mathrm{~g} / \mathrm{h}$; concentração de massa: 1,0\% de $\mathrm{O}_{3}$; aplicação do ozônio por difusão (difusor cerâmico) em coluna de contato; alimentação de oxigênio com fluxo de $0,68 \mathrm{Nm}^{3} / \mathrm{h}$ e pressão de 1,0 bar; refrigeração à água; temperatura do refrigerante: ambiente $\left(22^{\circ} \mathrm{C}\right)$ e volume da batelada: 11,04 litros. A Figura 1 mostra o gerador de ozônio, a coluna de contato onde fica armazenado o efluente para tratamento por ozonização e o medidor de ozônio.

Oxidação com Dióxido de cloro

A forma usada para a geração do dióxido de cloro em solução concentrada foi através da tecnologia SVP-Pure ${ }^{\circledR}+$ Purate $^{\circledR}$, patenteada pela empresa Eka Chemicals do Brasil S.A., onde são utilizados dois produtos químicos, o Purate ${ }^{\circledR}$ e o ácido sulfúrico a 78\%. O Purate ${ }^{\circledR}$ é uma solução de clorato de sódio e peróxido de hidrogênio. O SVP-Pure ${ }^{\circledR}$ é o gerador de $\mathrm{ClO}_{2}$.

$\mathrm{O}$ clorato de sódio é reduzido pelo peróxido de hidrogênio e ácido sulfúrico, onde o peróxido de hidrogênio é consumido na reação química.
A produção do $\mathrm{ClO}_{2}$ ocorre de acordo com a Equação 1:

$$
\begin{aligned}
& \left(\mathrm{NaClO}_{3}+\frac{1}{2} \cdot \mathrm{H}_{2} \mathrm{O}_{2}\right)+\frac{1}{2} \cdot \mathrm{H}_{2} \mathrm{SO}_{4} " \\
& " \mathrm{ClO}_{2}+\frac{1}{2} \cdot \mathrm{O}_{2}+\frac{1}{2} \cdot \mathrm{Na}_{2} \mathrm{SO}_{4}+\mathrm{H}_{2} \mathrm{O}
\end{aligned}
$$

Para a geração do dióxido de cloro aplicado nos testes de oxidação foi utilizado um gerador de escala comercial marca SVP-Pure ${ }^{\circledR}$, modelo AD. Do equipamento foi retirada uma amostra de um litro do concentrado de $\mathrm{ClO}_{2}$ para posterior aplicação no efluente. Durante a semana dos testes a amostra de $\mathrm{ClO}_{2}$ foi preservada dentro de frasco de vidro âmbar e em refrigerador. Para a aplicação do dióxido de cloro no efluente foi utilizada uma unidade experimental composta por um floculador para testes de bancada em escala de laboratório do tipo Jar-test, marca D.Tomé.

Osmose reversa

Para viabilizar o processo de filtragem do efluente por osmose reversa foi utilizado um tanque de alimentação com sistema de filtração acoplado a uma unidade de osmose reversa. Esta unidade de bancada possuía as seguintes características:

- Tanque de alimentação com capacidade para 20 litros contendo válvula de drenagem;

- Bomba 1: tipo centrífuga de baixa potência, marca Sictell cód 290429 , tensão $110 \mathrm{~V}$, freqüência $60 \mathrm{~Hz}$ e potência 36 Watts;

- Filtro de polipropileno, marca Pentek Filtration, modelo POLYDEPTH ${ }^{\circledR}$ PD-5-934 com faixa de operação em $5 \mu \mathrm{m}$, seguido de válvula de esfera de $1 / 2$ " para coleta de efluente;

- Bomba 2: tipo diafragma, marca Deng Yuan, modelo TYP-2600, ten- são AC $220 \mathrm{~V} / 24 \mathrm{~V}$ DC, freqüência $50 / 60 \mathrm{~Hz}$, pressão de 5,51 bar e fluxo aberto em 1,6 L/min;

- Filtro cartucho de carvão ativado em pó, marca Pentek Filtration, modelo Deluxe C-Séries C1, faixa de operação em $5 \mu \mathrm{m}$ usado para filtragem de cloro livre;

- Membrana de osmose reversa, marca CSM $^{\circledR}$, modelo RE1812-80, tipo TFC (Thin Film Composite) em poliamida enrolada em espiral, carga superficial negativa, rejeição ao $\mathrm{NaCl}$ em $96 \%$ e porosidade $\leq 0,0001 \mu \mathrm{m}$;

- Medidor de vazão/rotâmetro marca CENCO, n. ${ }^{\circ} 20.730$, série n. ${ }^{\circ} 385.634$ com escala de 0 a 15 L.O $/$ min posicionado na saída do permeado para aferição da vazão.

A Figura 2 apresenta o fluxograma da configuração do sistema durante os dois testes.

Coagulação-floculação

Para os ensaios de coagulação-floculação foram utilizados três coagulantes e dois auxiliares de coagulação. As principais características físico-químicas dos produtos são apresentadas (Tabela 4).

Para os ensaios de coagulação, floculação e sedimentação utilizou-se a unidade experimentaçl tipo Jar-test de características idênticas ao usado no teste oxidação com $\mathrm{ClO}_{2}$.

\section{Equipamentos}

Os equipamentos utilizados para as análises foram:

- Termômetro e condutivímetro digital marca SCHOTT Glaswerke Mainz, modelo Handylab LF1 com célula de condutividade modelo LF 613T;

- pHmetro digital marca PHTEK, modelo PHS-3B;

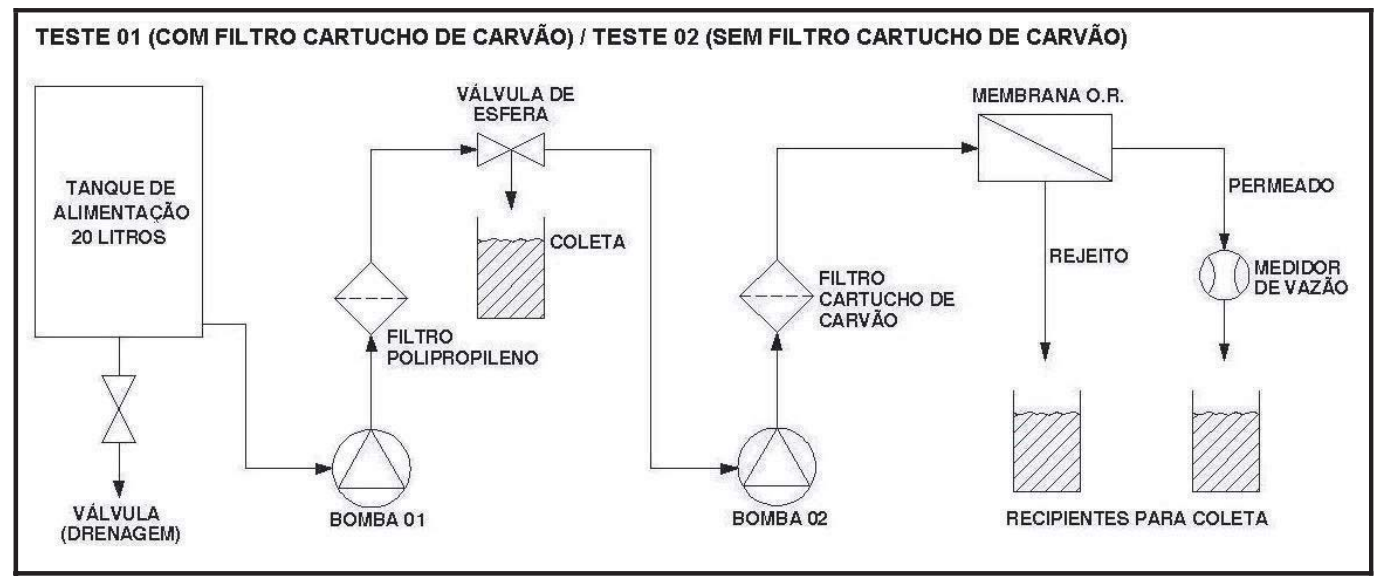

Figura 2 - Fluxograma da unidade de bancada de osmose reversa 
Tabela 4 - Resumo das características dos coagulantes e polieletrólitos usados no jar-test

\begin{tabular}{cccccccccc}
\hline Produto & Tipo & Fabricante & $\begin{array}{c}\text { Base do } \\
\text { produto }\end{array}$ & Densidade & $\begin{array}{c}\text { Carga } \\
\text { elétrica }\end{array}$ & $\begin{array}{c}\text { Peso } \\
\text { molecular }\end{array}$ & $\begin{array}{c}\text { Forma de } \\
\text { apresentação }\end{array}$ & Cor & $\mathrm{pH}$ \\
\hline Bufloc 5122 & Coagulante & Buckman & $(2)$ & Alta & Catiônico & Baixo & Líquido & Âmbar & $0,55^{(3)}$ \\
$\mathrm{Al}_{2}\left(\mathrm{SO}_{4}\right)_{3} \mathrm{PA}$ & Coagulante & Quimibrás & $\mathrm{NI}$ & $\mathrm{NI}$ & Catiônico & $\mathrm{NI}$ & Grânulos & Branco & $3,80^{(4)}$ \\
$\mathrm{PE019}$ & Coagulante & GE Betz & $(2)$ & $\mathrm{NI}$ & Catiônico & Baixo & Líquido & Âmbar & $0,95^{(3)}$ \\
Bufloc 565 & $\begin{array}{c}\text { Auxiliar de } \\
\text { coagulação }\end{array}$ & Buckman & ${ }^{(1)}$ & Baixa & Aniônico & Alto & Emulsão & Opaca & $7,80^{(3)}$ \\
F11 & $\begin{array}{l}\text { Auxiliar de } \\
\text { coagulação }\end{array}$ & GE Betz & $\left({ }^{(1)}\right.$ & NI & Aniônico & Alto & Pó & Branco & $6,000^{(5)}$ \\
\hline
\end{tabular}

${ }^{(1)}$ Poliacrilamida, ${ }^{(2)}$ Poliamina, ${ }^{(3)}$ Sem diluição, ${ }^{(4)}$ Solução a $1 \%,{ }^{(5)}$ Solução a $0,1 \%$, NI:Não Informado.

- Turbidímetro marca DEL LAB, modelo DLM 2000B (microprocessado);

- Analisador de carbono orgânico marca Shimadzu, modelo TOC-V CPH;

- Balança analítica digital marca SARTORIUS, modelo BL210S, precisão de 1 x $10^{-4}$;

- Estufa marca ODONTOBRÁS, modelo 1.1;

- Medidor/comparador de cor tipo Aqua Tester marca DEL LAB, modelo DNLH -100;

- Colorímetro marca HACH, modelo DR/890 com calibração de leitura para $530 \eta \mathrm{m}$.

\section{Métodos}

Métodos para caracterização do efluente

As análises para $\mathrm{pH}$, Turbidez, Cor, DQO, DBO, , COT, Carbono Inorgânico, Carbono Total, ST, SST, SDT, Condutividade, Coliformes Totais e Coliformes Fecais foram realizadas de acordo com o Standard Methods for the Examination of Water and Wastewater (APHA, 1998).

\section{Metodologia empregada para as tecnologias}

\section{Carvão Ativado}

Foi determinado o tempo de contato e a taxa de adsorção do carvão ativado através de testes em batelada. Retirou-se amostra de efluente com tempo de 5, 10, 15, 20, 30, 45, 60, 75 e 90 minutos para determinação do tempo de contato. Para a determinação da taxa de adsorção pesou-se carvão em grão moído passante em malha 325 (ASTM) nos percentuais de peso de carvão referente ao volume da amostra $0,0125 \%(0,05 \mathrm{~g}), 0,025 \%(0,10 \mathrm{~g})$, $0,05 \%(0,20 \mathrm{~g}), 0,075 \%(0,30 \mathrm{~g})$, $0,10 \%(0,40 \mathrm{~g}), 0,15 \%(0,60 \mathrm{~g}), 0,20 \%$ $(0,80 \mathrm{~g})$ e $0,25 \%(1,00 \mathrm{~g}), 0,3 \%(1,20 \mathrm{~g})$, $0,35 \%(1,40 \mathrm{~g})$ e $0,40 \%(1,60 \mathrm{~g})$. Após os testes, o efluente foi filtrado em papel filtro qualitativo marca Frama e medidos os parâmetros.

\section{Oxidação com Ozônio}

Foram realizados dois testes, um com efluente tratado e outro com o efluente tratado e filtrado. A duração total dos testes foi de 15 minutos cada, sendo retirada uma alíquota de $500 \mathrm{~mL}$ para análise com os tempos de 1, 2, 4, 6, 8, 10 e 15 minutos. A dosagem de ozônio gerado durante os testes era fixa em 13,5 mg/L.min. Esta dosagem foi obtida através da divisão da massa de ozônio aplicada (149,5 mg/min) pelo volume de efluente (11,04 L).

\section{Oxidação com Dióxido de cloro}

Foram realizados dois testes, um com efluente tratado e outro com o efluente tratado e filtrado. Foi determinada a demanda por $\mathrm{ClO}_{2}$ para os dois testes aplicando $5 \mathrm{ppm}$ de $\mathrm{ClO}_{2} \mathrm{em}$ Becker contendo $600 \mathrm{~mL}$ de efluente. A análise do residual de $\mathrm{ClO}_{2}$ ocorreu através de coletas de amostras de $25 \mathrm{~mL}$ com tempo de contato 5, 15, 30, 45 e 60 minutos e preparadas para análise em colorímetro. Os residuais estabilizados nas amostras de $0,26 \mathrm{mg} / \mathrm{L} \mathrm{e}$ $0,25 \mathrm{mg} / \mathrm{L}$ de $\mathrm{ClO}_{2}$ obtidos após 60 minutos para efluente tratado e efluente tratado e filtrado respectivamente ficaram entre $0,1 \mathrm{mg} / \mathrm{L}$, concentração mínina sugerida pela Eka Chemicals (Contato Pessoal, 2006), e $0,8 \mathrm{mg} / \mathrm{L}$, máximo permitido pela EPA
(1994). Após determinado o residual procedeu-se os ensaios de oxidação com três Becker's contendo 900 mL de efluente cada adicionando a dose de $\mathrm{ClO}_{2}$ determinado no ensaio de demanda.

\section{Osmose reversa}

Foram realizados dois testes, sendo o primeiro (Teste 01 ) com a utilização do filtro cartucho de carvão e o segundo (Teste 02) sem este filtro. Estas configuraçōes foram propostas para poder avaliar se o filtro cartucho de carvão estaria ou não auxiliando na filtração. Então, efetuou-se a limpeza do sistema e a determinação da vazão de projeto. Após filtrou-se o efluente por $180 \mathrm{mi}$ nutos coletando amostras do permeado com 15, 30, 60, 90, 120 e 180 minutos para caracterização.

Coagulação-floculação

Foram realizados três testes com os coagulantes e polieletrólitos. Os produtos do Teste 01 foram o PE019 + F11. No Teste 02 foram utilizados o $\mathrm{Al}_{2}\left(\mathrm{SO}_{4}\right)_{3}$ P.A. + F11 e, no Teste 03 os produtos Bufloc 5122 + Bufloc 565. Inicialmente se determinou a melhor faixa de $\mathrm{pH}$ e o tempo de sedimentação ideal. Após determinou-se a concentração ótima para os coagulantes e, por fim, com a concentração dos coagulantes fixa, determinou-se a concentração dos polieletrólitos.

\section{Avaliação dos custos diretos das tecnologias}

A metodologia para o levantamento dos custos envolvidos em cada item do tratamento levou em consideração: (1) Capital fixo: o custo dos equipa- 
mentos foi obtido através de consulta às empresas fornecedoras das tecnologias deste estudo e a empresas parceiras indicadas por estas considerando uma configuração baseada nas características do efluente tratado, os dados obtidos nos ensaios de bancada para cada tecnologia e uma vazão contínua de projeto de $2,5 \mathrm{~m}^{3} / \mathrm{h}$; (2) Depreciação: o tempo de depreciação utilizado para o capital fixo investido foi de dez anos; (3) Custo de manutenção: 4\% sobre o valor do capital fixo para bombas e acessórios, 2\% para manutenção de tubulaçôes e $2 \%$ para manutenção de tanques (no caso da ozonização e $\mathrm{ClO}_{2}$ e coagulação-floculação), segundo Peter e Timmerhaus (1991); (4) Custo de operação e (5) Custo dos insumos, também segundo fornecedores e; (6) Custo de energia elétrica: produto do consumo energético de bombas e equipamentos pelo valor do $\mathrm{kWh}$ conforme contrato da empresa com a concessionária local.

\section{RESULTADOS E DISCUSSÃO}

\section{Característica média das remessas do efluente tratado por lagoas}

Baseado nas seis coletas do efluente tratado relacionadas na Tabela 3 , é apresentado a seguir os valores médios de cada parâmetro caracterizado:

Faixa $\mathrm{pH}=8,1$ e 10,6; Turbi$\mathrm{dez}=10$ NTU; Cor= 341 Hazen; $\mathrm{DQO}=132 \mathrm{mg} / \mathrm{L} ; \mathrm{DBO}=50 \mathrm{mg} / \mathrm{L}$; $\mathrm{CT}=89 \mathrm{mg} / \mathrm{L} ; \mathrm{COT}=45 \mathrm{mg} / \mathrm{L}$; $\mathrm{CI}=44 \mathrm{mg} / \mathrm{L} ; \mathrm{ST}=1.617 \mathrm{mg} / \mathrm{L}$; $\mathrm{SST}=49 \mathrm{mg} / \mathrm{L} ; \mathrm{SDT}=1.568 \mathrm{mg} / \mathrm{L} ; \mathrm{Co}-$ liformesTotais $=2.620 \mathrm{NMP} / 100 \mathrm{~mL}$, e Coliformes Fecais $=18 \mathrm{NMP} / 100 \mathrm{~mL}$.

Para o caso dos coliformes totais a média simples é baseada em cinco coletas, sendo excluído o valor da $4^{\mathrm{a}}$ remessa por estar fora dos padrōes das demais.

\section{Comportamento dos parâmetros no efluente:}

\section{Carvão Ativado}

Após a determinação do tempo de contato e da taxa de adsorção do carvão ativado, verificou-se que este tempo ficou em torno de 20 minutos com uma adsorção de 20,03\% para o parâmetro DQO. A tecnologia não foi efetiva na redução do $\mathrm{pH}$ que durante a determinação do tempo de contato ficou em 9,5 e durante a determinação da taxa de adsorção em 10,5. Para os coliformes totais e fecais, estes parâmetros tiveram suas análises prejudicadas no decorrer do teste, uma vez que na análise do efluente utilizado nos testes caracterizou ausência destes coliformes. Para uma concentração de 0,60 gramas o carvão proporcionou remoção de $72,5 \%$ do carbono total (CT), de $91,5 \%$ do carbono orgânico total (COT). Porém, não houve remoção do carbono inorgânico $(\mathrm{CI})$. A cor ficou em 2,5 Hazen com remoção de 99,5\% (ver Tabela 5).

\section{Oxidação com Ozônio}

Para os dois testes executados, o teste 02, com o efluente filtrado, apresentou os melhores resultados. Porém, tanto no teste 01 como no teste 02 o pH caiu em média de 9 para 8,5 e os coliformes totais e fecais tiveram remoção de $100 \%$ para os 15 minutos de teste. Nos demais parâmetros o teste 02 obteve melhor eficiência de remoção. Para o teste 02 houve redução na DQO de $24 \%$ ficando em $46 \mathrm{mg} / \mathrm{L}$ e a cor de $74,5 \%$ caindo para 26 Hazen. Para o COT houve remoção de $17 \%$, para a turbidez de $45,5 \%$, os SST de $46 \%$. Os ST e SDT não obtiveram redução. Pôde-se perceber nos dois testes que, com o passar do tempo de contato, praticamente todos os parâmetros sofriam redução, a exceção dos SDT e ST que acabaram tendo ligeiro aumento (ver Tabela 5).

\section{Oxidação com Dióxido de cloro}

Os ensaios de demanda de $\mathrm{ClO}_{2}$ indicaram uma concentração de $5 \mathrm{ppm}$ e o tempo para estabilização do residual ficou em 60 minutos. Com estes dados calculou-se o fator $\mathrm{CT}_{\mathrm{D}}$ (concentração x tempo), ou seja, a concentração $(\mathrm{C}$, em ppm) do residual de $\mathrm{ClO}_{2}$ e o tempo de contato ( $\mathrm{T}$, em min) pela a equação: $\mathrm{CT}_{\mathrm{D}}=$ Concentração x Tempo. A dose encontrada foi de $\mathrm{CT}_{\mathrm{D}}=300 \mathrm{mg} \cdot \mathrm{min} / \mathrm{L}$. Os resultados dos ensaios mostraram que o teste 02 apresentou melhor eficiência de remoção que o teste 01 . Para o teste 02 houve redução de $\mathrm{pH}$ em média de 0,5 ponto. Os coliformes totais e fecais tiveram remoção de $100 \%$ após os 60 minutos de teste. Houve redução média da DBO de 59,5\% e da DQO de $13 \%$. A cor teve remoção de $75 \%$ caindo para 40 Hazen. Para os COT, CI, CT, ST, SST e turbidez não houve reduçôes significativas. Já para os SST a redução foi de $40,5 \%$ no teste 02 (ver Tabela 5).

\section{Osmose reversa}

$\mathrm{Na}$ osmose reversa, tanto o teste 01 com filtro cartucho de carvão, como o teste 02 sem este filtro, o permeado apresentou ótima qualidade, tendo o teste 02 uma eficiência de remoção ainda maior. Durante os 180 minutos do teste 02 o pH ficou neutro e os coliformes totais e fecais tiveram remoção de $100 \%$ durante todo o teste, comprovando a capacidade de desinfecção da tecnologia. A turbidez obteve remoção média de $96 \%$, a condutividade 95\%, e a DQO e cor de 98\%. Para o CT, COT e CI houve remoção de $98 \%$, $100 \%$ e $97 \%$ respectivamente. Para os ST, SST e SDT houve redução de $97,5 \%, 100 \%$ e $97,5 \%$ respectivamente (ver Tabela 5).

\section{Coagulação-floculação}

Os resultados obtidos durante os três testes com os coagulantes e auxiliares de coagulação comprovaram a melhor eficiência de remoção dos constituintes para o teste 03 , no jarro com concentração de 160 ppm de Bufloc 5122 e 0,5 ppm de Bufloc 565. Para estas concentrações houve queda de $22 \%$ no $\mathrm{pH}$ que estabilizou em 7,5. A DQO teve remoção 79\% e a cor de $95 \%$. Para o CT, COT e CI houve remoção de 58,5\%, 79\% e $16 \%$ respectivamente. Para a turbidez houve remoção de $94 \%$ e para os SST de $96,5 \%$. Porém o tratamento não foi eficiente para remoção dos ST e SDT que acabaram tendo ligeiro aumento de $1 \%$ e $4,5 \%$ respectivamente (ver Tabela 5).

\section{Avaliação da eficiência de remoção das tecnologias em relação aos critérios de reúso adotados}

Analisando qualitativamente os parâmetros do efluente tratado por carvão ativado, estes se mostraram muito satisfatórios em comparação com os requisitos adotados na Tabela 2 
para reúso do efluente. Tanto no teste para de terminação do tempo de contato com tempo a partir de 5 minutos, como no teste da determinação da taxa de adsorção com concentração a partir de 0,30 gramas, os parâmetros $\mathrm{DQO}$, DBO (uma vez que a DBO é sempre menor ou igual à $\mathrm{DQO}$ ), cor turbidez e DBO atenderam aos requisitos das quatro opçóes de reúso na indústria. Com esta qualidade o efluente poderia ser usado até como água de alimentação do tanque de pintura cataforética onde as concentrações máximas para $\mathrm{DQO}$ e $\mathrm{DBO}$ são de $15 \mathrm{mg} / \mathrm{L}$ e $10 \mathrm{mg} / \mathrm{L}$, respectivamente. Porém, o $\mathrm{pH}$, não sofreu ação do tratamento e se manteve fora da faixa (entre 6 e 9) de aceitação para todos os tipos de reúso proposto (ver Tabela 5).

No caso do efluente oxidado por ozônio, observou-se que, tanto o efluente tratado (teste 01 ) como o filtrado (teste 02) apresentaram limitaçôes para atender aos requisitos adotados na Tabela 2. Levando em consideração o efluente filtrado do teste 02 para o tratamento com 15 minutos de tempo de contato, este apresentou melhores resultados que o teste 01 , porém, ainda não atenderia de forma completa aos requisitos de nenhuma das quatro categorias de reúso propostas. Os parâmetros ST, SST e SDT superam os limites para reúso no processo de pintura e os ST e SDT para torres de resfriamento (Tabela 5). No caso do pH, este ficou acima do recomendado apenas para o reúso na pintura e a turbidez superou o limite $(2 \mathrm{NTU})$ em dois potenciais locais de reúso: processo de pintura e lavagem de pisos e irrigação de áreas verdes (Tabela 5). A cor também não atendeu a nenhum potencial local de reúso que possuísse diretriz especificada.

Fazendo a avaliação do efluente oxidado por dióxido de cloro para reutilização, também observou-se que, tanto o efluente tratado (teste 01 ) como o filtrado (teste 02) não estariam aptos para atender de uma só vez a todos os requisitos adotados na Tabela 2 . Apenas os resultados para $\mathrm{pH}$, coliformes totais e fecais estariam dentro da faixa de aceitação para os quatro locais de reúso proposto. A concentração de DBO estaria de acordo para reúso nas torres de resfriamento, processo de pintura e descarga sanitária (Tabela 5). Os SST e a condutividade estariam de acordo para reúso apenas nas torres de resfriamento. Já os demais parâme- tros analisados ou não atenderam ou não possuíam requisitos para reúso.

Para o caso do efluente filtrado por osmose reversa, observou-se que, tanto o permeado do teste 01 como do teste 02 apresentaram muito bons resultados em comparação aos requisitos adotados na Tabela 2 . Os parâmetros, $\mathrm{pH}$, turbidez, cor, DQO, DBO, ST, SST, SDT, coliformes totais e coliformes fecais tanto do teste 01 como do teste 02 , atenderam plenamente as quatro categorias propostas para reúso (Tabela 5). Pode-se afirmar ainda, que as concentraçôes de DQO e DBO destes efluentes filtrados estão abaixo do limite de $15 \mathrm{mg} / \mathrm{L}$ para DQO e $10 \mathrm{mg} / \mathrm{L}$ para $\mathrm{DBO}$ e estariam aptos a serem usados diretamente como água de alimentação para o tanque de imersão da pintura cataforética. Para a condutividade, a média de $73 \mu \mathrm{S} / \mathrm{cm}$ para o teste $01 \mathrm{e}$ de $53 \mu \mathrm{S} / \mathrm{cm}$ para o teste 02 , permitiria o reúso em torres de resfriamento e para as demais finalidades propostas, uma vez que não há diretrizes especificadas para os demais locais de reúso.

No caso do jarro com 150 ppm de Bufloc 5122 e 0,5 ppm de Bufloc 565 tratado por coagulação-floculação, observou-se que a DQO, DBO e cor atenderam as diretrizes para reúso em torres de resfriamento e processo de pintura (Tabela 5). O pH, turbidez e os SST obtiveram resultados ainda melhores e estariam aptos a atender as quatro categorias propostas para reúso. Já, os ST e SDT estariam acima do permitido para todas as categorias de reúso propostas (Tabela 5). Para os valores de coliformes totais e fecais, estes não foram analisados devido à conhecida falta de eficiência da tecnologia no que diz respeito à desinfecção.

Porém, deve-se lembrar que, levados em consideração todos os parâmetros conjuntamente, e não de forma isolada, o efluente tratado por coagulação-floculação não estaria apto a ser usado em nenhum dos quatro locais propostos para reúso devido ao excesso de SDT. Entretanto, todas as demais tecnologias propostas seriam beneficiadas pelo uso da coagulação/floculação como pré-tratamento, já que esta baixou sensivelmente a DQO, cor, COT, SST e turbidez. Ainda seria possível viabilizar o reúso desta tecnologia, recomendando uma revisão para o critério do SDT permitindo assim o uso deste efluente tratado por coagulação/floculação.
Para os cinco testes, com exceção do carvão e coagulação/floculação, foi utilizado efluente com pré-tratamento com o intuito de obter melhor eficiência do mesmo. Para os custos, foi previsto pré-tratamento com filtro de areia para o carvão e filtros de polipropileno para ozônio, $\mathrm{ClO}_{2}$ e osmose reversa. Para a coagulação/floculação não foi previsto custo do pré-tratamento. A comparação completa da eficiên-cia de remoção das tecnologias em relação aos critérios adotados para os quatro locais de reúso pode ser observada na Tabela 5 .

\section{Avaliação dos custos diretos das tecnologias}

Considerando a metodologia citada na seção Avaliação dos custos diretos de tecnologias, foi estimado o custo para as cinco tecnologias testadas no estudo subdividindo os valores em cinco itens conforme apresenta-dos na Tabela 6. O custo por metro cúbico da água de reúso tratada foi obtido através da soma dos cinco itens que compunha o preço, dividido pela geração de água de reúso anual da estação, que foi estimada em $20.580 \mathrm{~m}^{3}$ /ano.

De posse dos valores orçados no mercado e pelas empresas fornecedoras das tecnologias converteu-se o valor de cada item em Real para o valor em Dólar americano, que no dia 30/10/2006 possuía cotação de US\$ $1,00=\mathrm{R} \$ 2,14$. Observou-se que o menor custo obtido foi com a oxidação via ozônio (US\$ $0,54 / \mathrm{m}^{3}$ ), seguido pela oxidação com dióxido de cloro (US\$ 0,71/m 3 ). Em terceiro lugar aparece o tratamento com carvão ativado (US\$ $1,14 / \mathrm{m}^{3}$ ), seguido pela coagulação-floculação (US $\left.\$ 1,57 / \mathrm{m}^{3}\right)$. A osmose reversa, como era esperado, foi a tecnologia com maior custo de tratamento (US\$ $\left.1,70 / \mathrm{m}^{3}\right)$.

Neste trabalho não foram considerados os custos de infra-estrutura até as estações de reúso, nem computados os custos de tratamento ou disposição dos subprodutos gerados como o lodo e a água de lavagem dos tratamentos por carvão ativado e coagulação/floculação. Na Tabela 7 é apresentado o custo por item de composição do preço e pode-se notar que o maior percentual desta composição está relacionado aos custos de operação e insumos, sendo seguido pelo valor do investimento (Custo Fixo). 


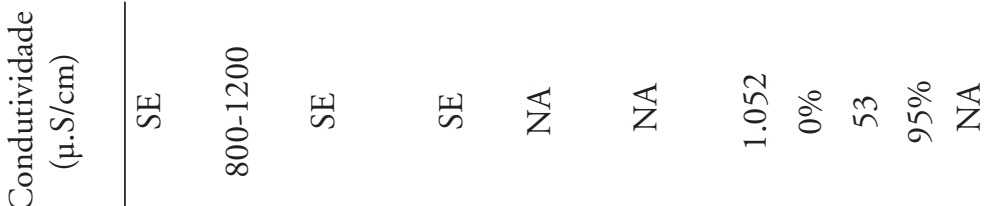

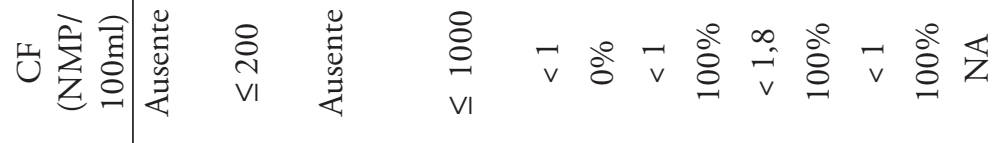

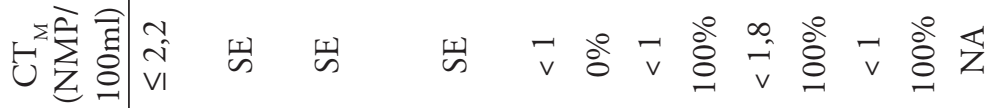

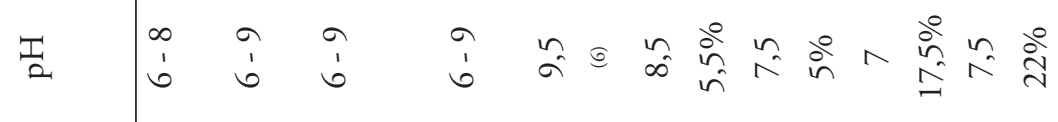

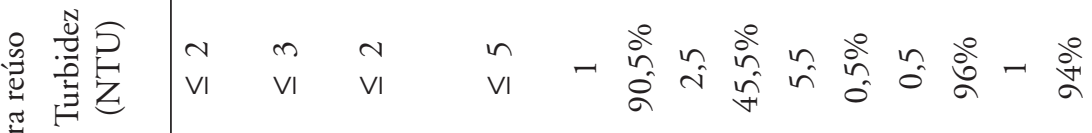

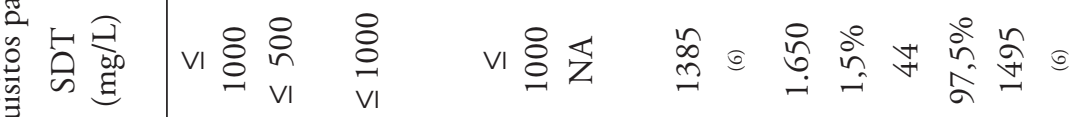

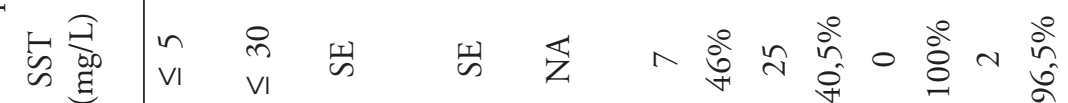

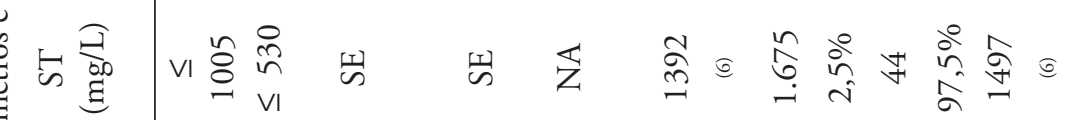

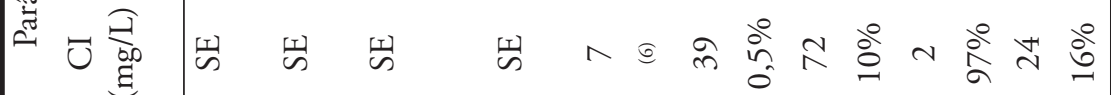

ठ



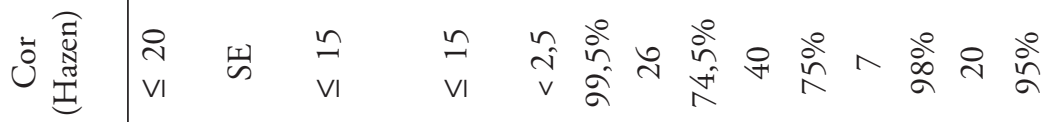

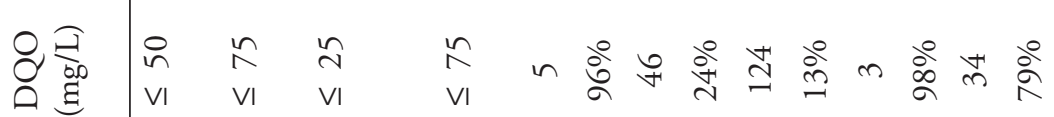

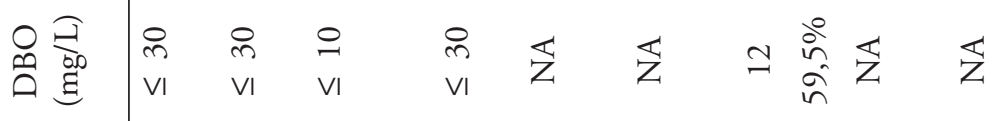

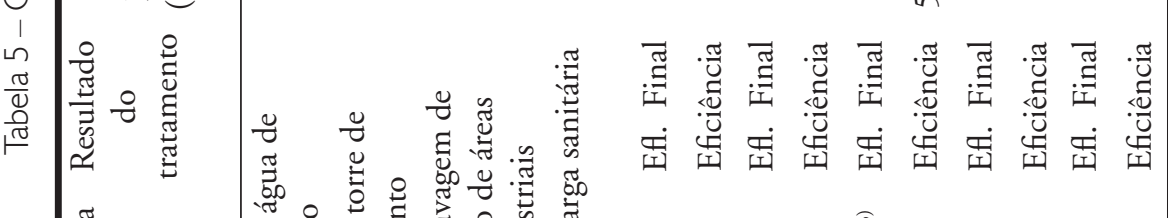


Tabela 6 - Configuração das tecnologias para o levantamento de custos

\begin{tabular}{|c|c|c|}
\hline Composição & Tecnologia & Configuração e custo do tratamento ${ }^{(1)}$ \\
\hline \multirow[t]{5}{*}{ Custo Fixo ${ }^{(2)}$} & Carvão Ativado & $\begin{array}{l}\text { Sistema de tratamento contendo } 2 \text { filtros de carvão com } 1160 \mathrm{~L} \text { cada, } 2 \text { bombas } \\
\text { centrífugas ( } 5 \text { e } 10 \mathrm{mca} \text { ), quadro e instalaçóes elétricas. Valor do capital: } \mathbf{R} \mathbf{\$ 4 6 . 0 1 0 , 0 0}\end{array}$ \\
\hline & Ozônio & $\begin{array}{l}\text { Sistema de pré-tratamento por filtro de PP, gerador de ozônio, concentrador de } \\
\text { oxigênio e bomba para } 4 \mathrm{~m}^{3} / \mathrm{h} \text {, reator para residência de } 15 \mathrm{~min} \text {, tubulaçōes e acessórios, } \\
\text { instrumentação e instalação elétrica. Valor do capital: } \mathbf{R} \mathbf{\$} \mathbf{7 9 . 0 6 0 , 0 0}\end{array}$ \\
\hline & Dióxido de Cloro & $\begin{array}{l}\text { Sistema de pré-tratamento por filtro de } \mathrm{PP} \text {, gerador de } \mathrm{ClO}_{2} \text {, tanques de produtos químicos, } \\
\text { bombas, tubulações, acessórios, instrumentação e inst. elétrica. Valor do capital: } \mathbf{R} \mathbf{\$ 8 4 . 8 3 0 , 0 0}\end{array}$ \\
\hline & Osmose reversa & $\begin{array}{l}\text { Sistema de pré-tratamento ( } 1 \text { bomba e filtro de areia e carvão) e unidade de osmose } \\
\text { reversa ROI } 0250124 \text { ( } 2 \text { bombas, filtro PP, resina catiônica, manômetros, medidor de } \\
\text { vazão e sistema de limpeza química). Valor do capital: } \mathbf{R} \mathbf{\$} \mathbf{7 6 . 5 0 0 , 0 0}\end{array}$ \\
\hline & Coag./Floculação & $\begin{array}{l}\text { Casa de química }\left(15 \mathrm{~m}^{2}\right) \text {, ETA de reúso para } 5 \mathrm{~m}^{3} / \mathrm{h} \text { (equipamentos, transporte e montagem } \\
\text { de todo o sistema) e bomba de recalque }\left(5 \mathrm{~m}^{3} / \mathrm{h} \text { x } 20 \text { mca). Valor do capital: } \mathbf{R} \mathbf{8 2 . 4 0 0 , 0 0}\right.\end{array}$ \\
\hline \multirow[t]{5}{*}{ Manutenção } & Carvão Ativado & Aplicado sobre o custo fixo de cada tecnologia um fator de manutenção de bombas \\
\hline & Ozônio & e acessórios de $\mathbf{4 \%}$ e um fator de manutenção de tubulação de $\mathbf{2 \%}$. \\
\hline & Dióxido de Cloro & $\begin{array}{c}\text { No caso da ozonização, dióxido de cloro e coagulação-floculação aplicou-se } \\
\text { ainda um fator adicional de manutenção para tanques }\end{array}$ \\
\hline & Osmose reversa & e reservatórios de $\mathbf{2 \%}$ \\
\hline & Coag./Floculação & \\
\hline \multirow[t]{5}{*}{ Operação } & Carvão Ativado & $\begin{array}{l}\text { 20\% da carga horária de } 1 \text { operador para o controle da ETA de reúso } \\
\text { (Salário R\$ 700,00/mês + 105\% de encargos sociais). R\$ 3.444,00/ano }\end{array}$ \\
\hline & Ozônio & $20 \%$ de 1 operador para o controle da ETA de reúso. $\mathbf{R} \$ \mathbf{3 . 4 4 4 , 0 0 / a n o}$ \\
\hline & Dióxido de Cloro & $20 \%$ de 1 operador para o controle da ETA de reúso. $\mathbf{R} \mathbf{3 . 4 4 4 , 0 0 / a n o}$ \\
\hline & Osmose reversa & $50 \%$ de 1 operador para o controle da ETA de reúso. $\mathbf{R} \$ \mathbf{8 . 6 1 0 , 0 0 / a n o}$ \\
\hline & Coag./Floculação & $100 \%$ de 2 operadores no controle da ETA de reúso. $\mathbf{R} \$ \mathbf{3 4 . 4 4 0 , 0 0 / a n o}$ \\
\hline \multirow[t]{5}{*}{ Insumos } & Carvão Ativado & $\begin{array}{c}\text { Areia grossa - 20L por filtro ( } 1 \text { troca/ano x } 2 \text { filtros) e carvão ativado - 1.160L } \\
\text { por filtro (12 trocas/ano). } \mathbf{R} \mathbf{3 8 . 3 1 0 , 0 0 / a n o}\end{array}$ \\
\hline & Ozônio & $\begin{array}{c}\text { Ventiladores ( } 3 \text { unid./ano), pastilha secadora de } \mathrm{O}_{2} \text { de } 2,5 \mathrm{~kg} \text { (1troca/ano) e filtro } \\
\text { de PP de } 5 \mu \mathrm{m}-2 \text { pç (12 trocas/ano). } \mathbf{R} \mathbf{4 . 2 7 0 , 0 0 / a n o}\end{array}$ \\
\hline & Dióxido de Cloro & $\begin{array}{l}\text { Clorito de sódio } 7,5 \% \text { (2.700 kg/ano), ácido clorídrico 9\% (2.592 kg/ano) e filtro } \\
\text { de PP de } 5 \mu \mathrm{m}-2 \text { pç (12 trocas/ano). R\$ } \mathbf{1 1 . 9 2 0 , 0 0 / a n o}\end{array}$ \\
\hline & Osmose reversa & $\begin{array}{l}\text { Filtro de areia - 180L ( } 1 \text { troca/ano }) \text {, carvão - } 225 \mathrm{~L} \text { ( } 2 \text { trocas/ano }) \text {, resina catiônica - } \\
\text { 225L ( } 1 \text { troca/ ano), filtro de PP de } 5 \mu \mathrm{m}-2 \text { pç }(12 \text { trocas/ ano }) \text { e membranas de O.R. } \\
\text { - } 12 \text { pç ( } 2 \text { trocas/ano }) . \mathbf{R} \mathbf{4 0 . 6 0 8 , 0 0 / a n o ~}\end{array}$ \\
\hline & Coag./Floculação & $\begin{array}{c}\text { Coagulante Bufloc } 5122 \text { (3.087 kg/ano), floculante Bufloc } 565(10,3 \mathrm{~kg} / \mathrm{ano}) \text {, } \\
\text { material filtrante - brita, areia e carvão antracitoso }(0,5 \text { troca/ano) e diafragmas da } \\
\text { bomba dosadora ( } 1 \text { troca/ano). R\$ } \mathbf{1 6 . 9 2 8 , 0 0 / a n o}\end{array}$ \\
\hline \multirow[t]{5}{*}{ Energia $^{(3)}$} & Carvão Ativado & $\begin{array}{c}\text { Consumo de } 4.527 \mathrm{kWh} / \text { ano referente } 1 \text { bomba centrífuga }(23 \mathrm{~h} / \mathrm{dia}) \text { e } 1 \text { bomba } \\
\text { centrífuga de retrolavagem }(1 \mathrm{~h} / \mathrm{dia}) . \mathbf{R} \mathbf{1 . 0 9 3 , 0 0 / a n o}\end{array}$ \\
\hline & Ozônio & $\begin{array}{c}\text { Consumo de } 8.257 \mathrm{kWh} / \text { ano referente ao gerador de ozônio }(24 \mathrm{~h} / \mathrm{dia}) \text { e } 1 \text { bomba } \\
\text { centrífuga }(24 \mathrm{~h} / \mathrm{dia}) \text {. R\$ } \mathbf{1 . 9 7 4 , 0 0 / a n o}\end{array}$ \\
\hline & Dióxido de Cloro & $\begin{array}{c}\text { Consumo de } 2.569 \mathrm{kWh} / \text { ano referente Gerador de } \mathrm{ClO}_{2}(24 \mathrm{~h} / \mathrm{dia}) \text { e } 1 \text { bomba } \\
\text { centrífuga para circulação }(24 \mathrm{~h} / \mathrm{dia}) . \mathbf{R} \mathbf{\mathbf { 6 1 4 } , \mathbf { 0 0 } / \mathbf { a n o }}\end{array}$ \\
\hline & Osmose reversa & $\begin{array}{l}\text { Consumo de } 28.963 \mathrm{kWh} / \text { ano referente } 1 \text { bomba centrífuga }(24 \mathrm{~h} / \mathrm{dia}), 1 \text { bomba } \\
\text { centrífuga de alta pressão }(24 \mathrm{~h} / \mathrm{dia}) \text { e } 1 \text { bomba dosadora }(1 \mathrm{~h} / \mathrm{dia}) \text {. R } \mathbf{\$} \mathbf{9 1 4 , 0 0 / a n o}\end{array}$ \\
\hline & Coag./Floculação & $\begin{array}{l}\text { Consumo de } 11.751 \mathrm{kWh} / \text { ano referente } 2 \text { agitadores mecânicos }(1 \mathrm{~h} / \text { dia }), 1 \text { floculador } \\
\text { mecânico }(24 \mathrm{~h} / \mathrm{dia}), 1 \text { bomba de recalque } 5 \mathrm{~m} 3 / \mathrm{h} \text { x } 20 \mathrm{mca}(24 \mathrm{~h} / \mathrm{dia}), 1 \text { bomba de } \\
\text { retrolavagem } 15 \mathrm{~m} 3 / \mathrm{h} \text { x } 10 \mathrm{mca}(0,5 \mathrm{~h} / \mathrm{dia}) \text { e } 1 \text { bomba dosadora }(24 \mathrm{~h} / \mathrm{dia}) . \mathbf{R} \mathbf{2 . 8 0 9 , 0 0 / a n o}\end{array}$ \\
\hline
\end{tabular}

Fonte: Companhia Paranaense de Energia Elétrica - COPEL.

${ }^{(1)}$ Sistema configurado para trabalhar 24 horas por dia com eficiência anual de 94\%, ou seja, 343 dias de operação anual (Peter e Timmerhaus, 1991), com geração estimada de água de reúso em $20.580 \mathrm{~m}^{3} / \mathrm{ano}$.

${ }^{(2)} \mathrm{O}$ capital foi depreciado em 10 anos, ou seja, ao custo anual do tratamento aplicou-se $10 \%$ do valor do capital.

${ }^{(3)}$ Custo da energia elétrica: R $\$ 0,23903 / \mathrm{kWh}$. 
Tabela 7 - Comparativo monetário por metro cúbico das tecnologias de tratamento avançado em relação à sua composição de custos

Composição

Tecnologias e custos de tratamento

\begin{tabular}{|c|c|c|c|c|c|c|c|c|c|c|}
\hline & \multicolumn{2}{|c|}{ Carvão Ativado } & \multicolumn{2}{|c|}{ Ozônio } & \multicolumn{2}{|c|}{$\begin{array}{c}\text { Dióxido de } \\
\text { Cloro }\end{array}$} & \multicolumn{2}{|c|}{ Osmose Reversa } & \multicolumn{2}{|c|}{$\begin{array}{l}\text { Coagulação } \\
\text { Floculação }\end{array}$} \\
\hline & $\mathrm{US} \$ / \mathrm{m}^{3}$ & $\%$ & $\mathrm{US} \$ / \mathrm{m}^{3}$ & $\%$ & $\mathrm{US} \$ / \mathrm{m}^{3}$ & $\%$ & $\mathrm{US} \$ / \mathrm{m}^{3}$ & $\%$ & $\mathrm{US} \$ / \mathrm{m}^{3}$ & $\%$ \\
\hline Total do tratamento & 1,14 & 100 & 0,54 & 100 & 0,71 & 100 & 1,70 & 100 & 1,57 & 100 \\
\hline Custo Fixo & 0,10 & 9,16 & 0,18 & 33,06 & 0,19 & 27,15 & 0,17 & 10,24 & 0,19 & 11,94 \\
\hline Manutenção & 0,06 & 5,49 & 0,14 & 26,45 & 0,15 & 21,72 & 0,11 & 6,14 & 0,15 & 9,55 \\
\hline Operação & 0,08 & 6,85 & 0,08 & 14,39 & 0,08 & 11,01 & 0,20 & 11,52 & 0,79 & 49,91 \\
\hline Insumos & 0,87 & 76,33 & 0,10 & 17,85 & 0,27 & 38,15 & 1,01 & 59,64 & 0,38 & 24,53 \\
\hline Energia & 0,03 & 2,17 & 0,04 & 8,25 & 0,02 & 1,97 & 0,21 & 12,46 & 0,06 & 4,07 \\
\hline
\end{tabular}

\section{CONCLUSÕES E RECOMENDAÇỖES}

\section{Conclusões}

Pôde-se concluir que as tecnologias de adsorção com carvão ativado e filtração por osmose reversa forneceram os melhores resultados em termos de qualidade do efluente para reúso. Em termos financeiros, o custo unitário de tratamento por adsorção em carvão ativado, que ficou em torno de US\$ $1,14 / \mathrm{m}^{3}$, é mais atrativo que o custo de US\$ $1,70 / \mathrm{m}^{3}$ apresentado pela osmose reversa.

A ozonização apresentou tratamento satisfatório apenas quando levado em consideração o teste com efluente filtrado (teste 02). Confirmouse a tradicional eficiência da ozonização na desinfecção dos coliformes totais e fecais do efluente e também na oxidação da cor. Porém o restante dos parâmetros não apresentou boa remoção inviabilizando sua reutilização na planta industrial. A oxidação via ozonização apresentou o menor custo unitário de tratamento, US\$ $0,54 / \mathrm{m}^{3}$.

$\mathrm{O}$ dióxido de cloro apresentou a menor eficiência entre as tecnologias testadas. $\mathrm{O}$ tratamento com $\mathrm{ClO}_{2}$, como na ozonização também foi efetivo na remoção de coliformes totais e fecais. A cor também obteve boa redução. A DBO e $\mathrm{pH}$ também reduziram, no entanto, em menores proporçôes. Os demais parâmetros não atenderam as diretrizes de reúso, inviabilizando a utilização do efluente nos quatro locais propostos. $\mathrm{O}$ custo do tratamento com $\mathrm{ClO}_{2}$ girou em torno de US\$ $0,71 / \mathrm{m}^{3}$.
No estudo com a coagulaçãofloculação os três testes apresentaram resultados satisfatórios, especialmente o teste 03. Para esta configuração, todos os parâmetros analisados para esta tecnologia, à exceção dos SDT, estavam aptos a atender as diretrizes de reúso em torres de resfriamento e processo de pintura. No tratamento com coagulação-floculação constatou-se também seu custo superior em relação ao carvão ativado, US $\$ 1,57 / \mathrm{m} 3$ contra US\$ $1,14 / \mathrm{m} 3$. Esta distorção no custo do tratamento pode ser decorrente: (1) da baixa vazão para a ETA de reúso, e (2) pela configuração proposta para o tratamento, utilizando polieletrólitos sintéticos.

\section{RECOMENDAÇÕES}

- Refazer os ensaios em batelada com carvão ativado e complementar o estudo com a instalação de uma coluna piloto de adsorção em carvão ativado.

- Complementar os estudos com osmose reversa utilizando uma unidade de alta pressão que possa viabilizar a filtração em circuito fechado.

- Utilizar combinações das tecnologias estudadas, como por exemplo: o uso da coagulação-floculação com carvão ativado.

- Avaliar técnica e economicamente as possibilidades de tratamento ou disposição dos rejeitos provenientes dos estudos propostos.

- Aperfeiçoar a avaliação econômica das tecnologias, realizando o levantamento de custos para configurações com maiores vazões.

\section{AGRADECIMENTOS}

Os autores agradecem as empresas Faurecia, Carbomafra, White Martins, Buckman Laboratórios, GE Infrastructure Water \& Process, Permution E. J. Krieger, Eka Chemicals e aos laboratórios LABEAM e CEPPA da UFPR pelo apoio na realização deste trabalho.

\section{REFERÊNCIAS}

APHA - AMERICAN PUBLIC HEALTH ASSOCIATION. Standard Methods for the Examination of Water and Wastewater. 20th ed. Washington: APHA-AWWA-WEF, 1200p, 1998.

ASANO, T. Wastewater reclamation and Reuse, Water Quality Management Library. Thecnomic Publishing Co. Inc.: Lancaster, PA v. 10, 1998.

BRASIL. Lei no $9.433-8$ jan. 1997. Institui a Política Nacional de Recursos Hídricos, cria o Sistema Nacional de Recursos Hídricos, regulamenta o inciso XIX do art. 21 da Constituição Federal e altera o art. $1^{\circ}$ da Lei no 8.001 , de 13 de março de 1990, que modificou a Lei $\mathrm{n}^{\circ} 7.990$ de 28 de dezembro de 1989. Diário Oficial da União, Brasília, Seção 1, p. 470.9 de janeiro de 1997.

EPA - ENVIRONMENTAL PROTECTION AGENCY. Guidelines for Water Reuse. EPA/625/ R-04/108, Washington, DC, September, 450 p, 2004.

EPA - ENVIRONMENTAL PROTECTION AGENCY. National Primary Drinking Water Regulations; Disinfectants and Disinfection Byproducts; Proposed Rule. EPA 815-R-99-014, Federal Register Environmental Documents: July 29, 1994.

FLORENCIO, L; BASTOS, R. K. X.; AISSE, M. M., (Coordenadores). Tratamento e utilização de esgotos sanitários. FINEP/PROSAB 4 Tema 2, Rio de Janeiro, 427p., 2006.

METCALF \& EDDY, INC. Wastewater engineering: treatment and reuse. 4th. ed. - New York: McGraw-Hill, 1819 p, 2003. 
MANCUSO, P. C. S.; SANTOS, H. F., Reúso de Água. NISAM - USP, Barueri, SP, 579 p, 2003.

MIERZWA, J. C. Água na indústria: uso racional e reúso. São Paulo: Oficina dos Textos, 143 p, 2005.

PETERS, M. S.; TIMMERHAUS, K. D., Plant design and economics for chemical engineers. 4th. ed. - New York: McGraw-Hill, 973 p, 1991.

TOMAZ, P. Previsão de consumo de água. MF - São Paulo: Navegar Editora, 250 p, 2000.

WESTERHOFF, G. P., Un update of research needs for water reuse. In: Water Reuse Symposium, 3, San Diego, California: Proceedings p. $1731-42,1984$.

WHO - WORLD HEALTH ORGANIZATION. Reuse of effluents: methods of wastewater treatment and health safeguards. Technical report series, Genebra: n. 517, 1973.

\section{Endereço para correspondência:}

\section{Airton Oenning Junior} Inotec do Brasil Ltda

Rua Presidente Beaurepaire

Rohan, 376 Cristo Rei

80050-340 Curitiba - PR - Brasil

Tel/Fax: (4I) 3363-0055

E-mail: airton@inotec.com.br 